\title{
'Forbidden Fruits' and the Communist Paradise: Marxist Thinking on Greekness and Class in Rebetika
}

\author{
YIANNIS ZAIMAKIS
}

No matter what the earth will turn red

[...] We will make sure of that ${ }^{1}$

\section{Introduction}

A deep-seated belief in the inevitable advent of a utopian communist society prompted the Greek Leftist intelligentsia to pave the way for the oncoming radical transformation of society, rescuing people from the "jail" of capitalist injustice. Considering themselves the avant-garde of the progressive movement, leaders of Marxist opinion had the strong sense that it was their duty to "humanize the masses" ${ }^{2}$ and to inculcate class-consciousness among the proletariat. Invoking various antithetical and evolutionary schemes, they were involved in a furious debate amongst intellectuals of all political inclinations about the cultural character of Greek identity - a debate that lasted from the late interwar period to the mid-1980s, and, to some extent, persists today.

In this essay, I examine rebetika texts drawn from the plethora of the writings that have been published in numerous dailies, magazines, and books since the 1930s. Some of them have been re-printed in later studies or collections. ${ }^{3}$ The publication of the Vlisidis's anthology of rebetika texts with 2396 references and brief descriptions of relevant writing has increased the availability of such sources. ${ }^{4}$ Furthermore, I rely upon Vlisidis's well-documented study of the discourse of the Greek Left. ${ }^{5}$ It is an important reference for scholarly work on rebetika, which has proliferated during the last decades. ${ }^{6}$

I wish to thank the rebetologist Kostas Vlisidis for his interesting advice and the litterateur Margarita Antoniou for her constructive comments on this paper.

${ }^{1}$ Extract from a militant poem of Volf Birman that expresses the leftwing belief in the advent of a classless "red" society and the vital role of Marxist intelligentsia in the enlightenment of people. The poem was set to music by the Left-wing composer

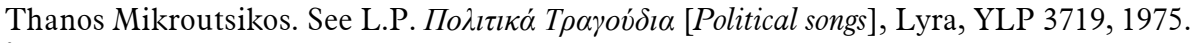

${ }^{2}$ Dafni Tragaki, "Humanizing the masses': Enlightened intellectuals and the music of the people," in, The Mediterranean in music: Critical perspectives, common concerns, cultural differences, ed. David Cooper and Kevin Dawe (Lanham: Oxford, 2005), 49-76.

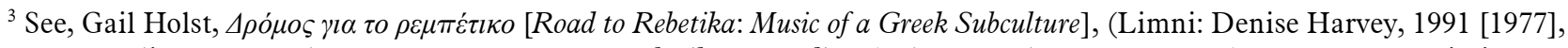

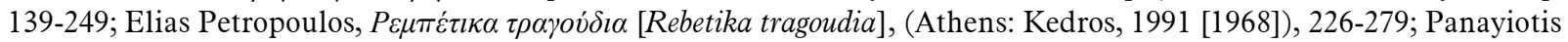

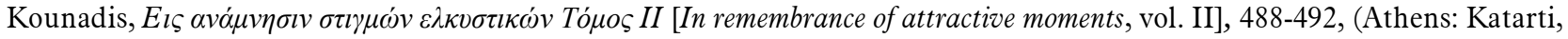

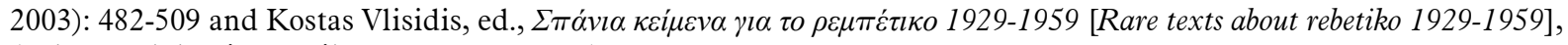
(Athens, Ekdoseis tou eikostou protou, 2006).

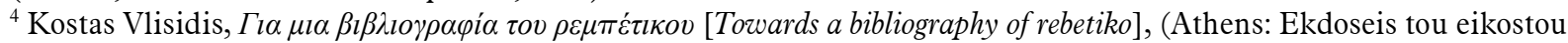
protou, 2002).

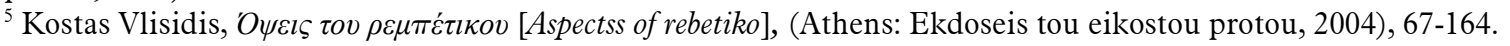

${ }^{6}$ See for example, Stathis Gauntlett, "Orpheus in the criminal underworld: Myth in and about Rebetika," Mantatoforos 34 (1991): 7-48; Stathis Gauntlett, “Rebetika and inter-war literature,” Kó $\mu \pi$ oৎ 13 (2005): 88-101; Dafni Tragaki, "Humanizing 
In this article my purpose is not so much to present another review of the debates about rebetika, but to take a thematic approach, tracing the basic applications of Marxist thought in Greek society to the relationship between popular music and politics. To this end, my analysis focuses on the use of music as a vehicle for educating people, preparing them for a new, grand socialist utopia. At the same time, it explores the ways in which Left intellectuals associated rebetika with the broader issues of the political and cultural struggle for hegemony. I hope this work will contribute to the ongoing discussion concerning the debates and ideological struggles that have occurred around issues of identity in a number of ethnic musical styles (for example rebetika, tango, fado, and flamenco) that were initially despised by local elites but today have become symbols of national culture. ${ }^{7}$ For this reason, I include a description of the genre's evolution and its association with issues of culture and identity in Greece. In addition, I identify some important similarities with other discourses and processes that have occurred in other countries worldwide.

\section{The evolution and transformation of rebetika}

During the opening ceremony of the 2004 Olympic Games in Athens, the director Dimitris Papadimitriou featured rebetika as a symbol of the rich cultural heritage of the nation. Some decades ago, the genre was scorned by puritans, nationalists, official state ideologues, and dogmatic Leftists, all of whom regarded it as an undesirable Anatolian residue of the Ottoman Empire and an immoral product of the urban underworld. The path towards the nationalization of rebetika was a long one, with many vicissitudes in the genre's domestic and foreign appeal. Originally, in the late nineteenth and early-twentieth century, rebetika was associated with some marginalized urban groups scattered around the brothels, tekedhes (hashish dens), and café-amans in the urban centers of Asia Minor (mainly in Constantinople and Smyrna) and the sea ports of Greece (mainly in Piraeus, Ermoupolis, Thessaloniki, Heraklion, Kavala, and Volos)..$^{8}$

The transition of rebetika from a non-commercial, grassroots, and orally transmitted music into a recorded genre took place with the beginning of the record industry in Greece and the increased availability of the gramophone during the early 1920s. ${ }^{9}$ At the time, the genre could be subdivided into two main styles. The first is the Piraeus or teke style, commonly accompanied by stringed instruments

\footnotetext{
the masses"; Dafni Tragaki, Rebetiko worlds (Cambridge: Cambridge Scholars Publishing 2005); Despoina Michael, "Tsitsanis and the birth of the "new' laiko tragoudi," Modern Greek Studies (Australia and New Zealand) 4 (1996): 55-96; Gail Holst-Warhaft, "The tame Sow and the wild boar hybridization and the rebetika," in Songs of the Minotur: hybridity and popular music in the era of globalization: a comparative analysis of rebetika, tango, Rai, Flamenco, Sardana and English urban folk, ed. Gerhard Steingress (Munster-Hamburg-London: LIT, Verlag 2002), 21-50; Yiannis Zaimakis, "Bawdy songs and virtuous politics: ambivalence and controversy in the discourse of Greek Left on rebetiko," History and Anthropology 20, no. 1 (2009): 1536.

${ }^{7}$ For a comparative approach to these styles see Peter Manuel, Popular music of the non-western world: an introductory survey (New York and Oxford, Oxford University Press, 1998); Gerhard Steingress, "Social theory and the comparative study of flamenco, tango, rebetika" in The passion of music and dance: body, gender and sexuality, ed. William Washabaugh (Oxford: Berg, 1998), 151-171; Gerhard Steingress, ed. Songs of the Minotaur: hybridity and popular music in the era of globalization, (MunsterHamburg-London: LIT Verlag, 2002).

${ }^{8}$ William Washabaugh, "Introduction: music, dance and the politics of passion," in The passion of music and dance: body, gender and sexuality, ed. William Washabaugh (Oxford: Berg, 1989), 20.

${ }^{9}$ Nicholas Pappas, "Concepts of Greekness: the recorded music of Anatolian Music after 1922," Fournal of Modern Greek Studies 17 (1999): 355. For the early recordings of rebetika and Asia Minor song in USA, Smyrna, Constantinople and Athens, see also, Ole Smith, "Cultural identity and cultural interaction: Greek music in the United States, 1917-1941," Fournal of Modern Greek Studies 17 (1999): 125-138.
} 
(bouzouki, baglama, and, later, the guitar), performed initially in hashish dens, and associated with marginal life in Greek urban centers. The second is the café aman style, performed by musicians from Asia Minor. It used musical instruments capable of producing microintervals such as ud, santouri, and violin. ${ }^{10}$ The subject matter of the rebetika lyrics included love, pain, sorrow, and hedonism, and their vocabulary was colored by the idiomatic slang of local maghes. ${ }^{11}$

One cannot grasp the significance of rebetika and its impact on modern Greek popular music without first understanding the role that the music of refugees from Asia Minor played in the development of the genre. In 1922, the war between Greece and Turkey, which ended with the defeat of Greek forces, had a major impact on the cultural character of the newly independent country. The compulsory exchange of populations between the two countries in the 1920s, dictated by the terms of the Treaty of Lausanne (1923), resulted in the ethnic homogenization of the populations in both countries.

The sudden influx of approximately 1.5 million newcomers fueled a debate on the issue of Greekness in cultural production and music. Local Greeks looked down on the newly imported Anatolian amanedes and the different habits of the refugees, perceiving them as "an Anatolian corruption of Greekness polluted by the Turkish language, Levantine mercantilism, and oriental customs." 12 Refugees regarded themselves as carriers of a rich cultural heritage. They had a developed identity tradition in the Ottoman Empire, the roots of which were thought to be continuous, from the famous Ancient Ionian to the glorious Byzantine period. ${ }^{13}$

During the first year of their arrival in mainland Greece, many refugees were in poor condition and some were outcasts, living in the outskirts of urban areas where they joined maghes hanging around hashish dens. During this period, a new proletarian audience embraced "lowbrow" songs that dealt with the themes of poverty, nostalgia, hashish-smoking, and disreputable living. ${ }^{14}$ As Pappas notes, "The shared conditions and economic plight between the newly arrived and despised refugees, on the one hand, and seedy, destitute communities of maghes, on the other, made the interaction between two styles creative and the "transfer of musical innovations and skills easier." 15 The interaction between the newly imported music colored by the rich cosmopolitanism of the recent Ottoman past led to rebetika that sprang up in Greek urban centers, achieving a popularity and "respectability hitherto unknown."16

Until the advent of amanedes, the Anatolian music of the refugees from Asia Minor, and the advent of recorded rebetika, the musical life of the Greek mainland was based on folk music connected with particular regions (i.e., Lyre music in Crete, the Clarinet of Epirus, and the music of the Aegean Sea islands, Maniot laments, and Thracian songs). The music of the developing urban centers was characterized by a diversity reflecting prevalent social divisions. The taste of the upper class was oriented

\footnotetext{
${ }^{10}$ For the subdivision of rebetika into these two main styles, see Risto Pekka Pennanen, "The development of chordal harmony in Greek rebetika and laika music, 1930 to 1960s," British Fournal of Ethnomusicology 6 (1997): 66; Holst-Warhaft, "Rebetika: the double-descended deep songs of Greece," in The passion of music and dance: body, gender and sexuality, ed. William Washabaugh, (Oxford: Berg, 1998), 113-15; Holst- Warhaft, "The tame sow," 21-50.

${ }^{11}$ A "tough man" associated with disreputable living and pleasure-seeking, who used a distinctive slang and dressed in a distinctive way that, as Sarbanes notes, melded "aspects of bourgeois dress (e.g., bow ties and collars, 'republika' hats) mixing them with more proletarian elements." See, Janet Sarbanes, " 'Mucking and communitas': the aesthetic mode of sociality in rebetika subculture," Popular Music and Society 29, no. 1 (2006): 20.

${ }^{12}$ Pappas, "Concepts of Greekness," 353.

${ }^{13}$ Mustafa Suphi Erden, "The exchanges of Greek and Turkish population in the 1920s and its socio-economic impact on life in Anatolia," Crime, Low and Social Change 41(2004): 275.

${ }^{14}$ Holst-Warhaft, "The double-descended deep song," 115.

${ }^{15}$ Pappas, “Concepts of Greekness," 359.

16 ibid., 354.
} 
towards western influenced music, ranging from European classical music and its popularized expression (i.e., operettas), to western or westernized types of light music (i.e., tango, cantata, waltz, fox-trot). At the same time the lower classes preferred kutsavakika oral traditions of the hashish den outcasts and folk tunes imported by domestic agrarian immigrants, and even, during the years of Greek Civil War (1946-49), the guerilla songs of the militant Left.

During the years of Metaxas's dictatorship (1936-1941), the regime made a concerted effort to censor the recordings of immoral and hashish songs and the amanedes, who were considered polluted by eastern sensibilities. In the post-war era, rebetika became more popular and were diffused among the wider social strata, often performed in the flourishing bouzouki taverns where the repertoire became more complex and hybridized. The wider use of chordal harmony in rebetika and the refining of lyrics made the genre more western and thus suited to the tastes of the new audience (including bohemian circles from middle and upper classes) and the demands of the market. ${ }^{17}$ Although the genre was on the decline during the mid-1950s, its innovative music was to influence the formation of newly created types of popular music in the next years (see the later section of this text). During recent decades, various revivals occurred, prompted in part by nostalgia for a lost primitivism. Today rebetika is regarded as a mainstream music and as a distinct national symbol that attracts the interest of foreign tourists, scholars, youths, students and the bohemians, who frequent the small bouzouki taverns. All of them seek the revitalizing of rebetika "spirit."

The cultural changes that occurred in the field of popular music during the first half of the twentieth century, specifically the changing cultural significance of rebetika, became the subject of a furious debate within Greek intelligentsia. A main topic of debate was the definition of the pure Greek cultural forms as distinguished from genres of Eastern, and particularly Turkish, origin and the formation of a nationalpopular song. Moreover, the Greek intelligentsia, which included many Marxists, had to negotiate the genre's associations with marginal social groups and lumpen-proletariat. ${ }^{18}$

\section{Debates on ethnic musical styles around the world}

During the last few decades, there has been a shift from the ethnocentric and essentialist perspectives of popular music to more comparative and critical approaches focusing on the dynamic, fluid, complex, and intercultural character of the evolution of ethnic musical styles. Rebetika development and the discourse of popular music within Greek intelligentsia can be seen as a regional example of the sort of processes associated with nationalization, modernization, and urbanization that occurred in many countries from the early-twentieth century to the decades immediately following World War II. During this period, the Balkans and other non-western European countries were coming into existence as political entities or were attempting to extend their borders, strengthening their social cohesiveness. Cultural elites and intellectuals covering the whole spectrum of political tendencies tried to approach the newly constructed musical styles and to define what kind of popular music could be viewed as proper national music.

\footnotetext{
${ }^{17}$ Pennanen, "The development of chordal harmony in Greek rebetika and laika music," 67.

${ }^{18}$ Lumpen-proletariat is a German term first coined by Karl Marx and Friedrich Engels in The German Ideology (1845) to describe the segments of the working class that would never achieve class consciousness, and was therefore an obstacle to the class struggle toward the revolutionary transformation of society. The term was widely used by left-wing intellectuals to describe the marginalized communities which were associated with rebetika.
} 
Since there are some parallels between the origins, evolution, and manipulation of many ethnic musical styles (rebetika, fado, tango, and flamenco) and the discourses that support them, a brief comparative exploration can help us link our topic to broader ideological and aesthetic issues. ${ }^{19}$ It should be acknowledged, however, that these similarities, as Holst-Warhaft points out, "should not blind us to the particular circumstances" ${ }^{20}$ under which each genre developed and transformed, not to mention the task of reexamining the social and cultural context of these styles in a more focused way, demystifying prevalent stereotypes and prejudices. ${ }^{21}$

The case of Argentinean tango supplies an example of a parallel debate concerning popular music. In its early stages, tango was scorned by the Eurocentric native aristocracy because of its ethnic "impurity" and its associations with slums and brothels. ${ }^{22}$ During the period between the two World Wars, tango spread and became popular throughout Argentina and then Europe. The Parisian bourgeoisie cleansed tango, offering a new, acceptable, and exotic version of a stylized tango while the Argentine aristocracy re-invented the genre as its own private genre. ${ }^{23}$ Argentineans treated tango as the quintessential expression of their own national character, tracing in its evolution the history of their identity. ${ }^{24}$

The ways in which local elites manipulate ethnic musical styles are evident in the case of Trinidadian steelband, which was transformed from a grassroots carnival street music of the urban poor into the national voice of Trinidad and Tobago. This transformation has been analyzed as a cultural process that involved negotiations between different ethnic groups and intellectual circles about the definition and use of popular music - negotiations that hinged on the interests and aspirations of the interlocutors. ${ }^{25}$

Similar contextual changes were found in Spanish flamenco and Portugal fado. According to Da Costa Holton's analysis, these musical styles emerged as the "cultural expression of marginalized communities, which were then popularized by mainstream." Today they are performed mainly for domestic and foreign tourists. ${ }^{26}$ Like rebetika fado was born in a social milieu marked by marginalization and has a long history of intense change and transformation. Fado became the subject of a strong debate concerning national identity and political affiliation. Many intellectuals connected fado with a mythical past, reflecting the eternal national soul, while others linked it to a cathartic expression of Portuguese working-class longings. ${ }^{27}$ Over the last several decades, new theories have challenged previously regnant impressionistic or ethnocentric notions by shifting the focus to transcultural, dynamic, and fluid aspects of the genre.

Flamenco was performed first in intimate Andalusian settings, among the marginal social groups and soon embraced by young Spanish playboys and philanthropist aristocrats, the so called senioritos. They

\footnotetext{
${ }^{19}$ In his work on the comparative history of flamenco, tango, and rebetika, Steingress points out some of the common peculiarities of these styles: the association with the process of modernization and "the transition from traditional agrarian pre-capitalistic societies into modern, urban, national capitalistic society," their initial connections with urban marginalized groups, and their highly sensitive attitudes related to love sorrow, pain, loneliness, and death. See, Gerhard Steingress, "Social theory and the comparative history of flamenco, tango and rebetika," 160-65.

${ }^{20}$ Holst- Warhaft, "Rebetika: the double-descended deep songs of Greece," 113.

${ }^{21}$ Steingress, "Social theory and the comparative history of flamenco, tango and rebetika," 151.

${ }^{22}$ Manuel, Popular music of the non-western world, 59, 61.

${ }^{23}$ Marta Savigliano, Tango and the political economy of passion (Boudler, San Francisco, Oxford: Westview Press, 1995 ), 166.

${ }^{24}$ Peter Manuel, Popular music of the non-western world, 59.

${ }^{25}$ Shannon Dudley, “The steelband 'own tune': nationalism, festivity, and musical strategies in Trinidad's Panorama competitions," Black Music Research Fournal 22 (2002): 13. For an insightful study of steelband music see Stephen Stuempfle, The steelband movement: The forging of a national art in Trinidad and Tobago (Philadelphia: University of Pennsylvania Press, 1995).

${ }^{26}$ Kimberly DaCosta Holton, "Like blood in your mouth: topographies of flamenco voice and pedagogy in diaspora," Texts and Performance Quarterly 18 (1998): 309.

${ }^{27}$ See for example, Paul Vernon, A history of the Portuguese Fado (Aldershot: Ashgate, 1998).
} 
frequented the dives and became admirers of the music of Andalusian proletariat. ${ }^{28}$ As Mitchell points out, flamenco challenged the theories of the racial mystification of flamenco as a genre with ancient, obscure, and oriental roots. Thus, the discourse of flamenco had to refine and neutralize the role of marginal groups in the evolution of the genre, in order to promote it as an exotic and passionate "pure" Spanish song. ${ }^{29}$ Flamenco was conscripted to serve political aspirations of both the cultural policy makers of Franco's fascist regime and of those who opposed them-and, like rebetika, the genre became the subject of various transformations and periodic revivals that attempted to restore flamenco puro. ${ }^{30}$

Scholarly examination of art in many countries shows that popular music was used as an important vehicle for the expression and consolidation of identity in the urbanization and nationalization process. ${ }^{31}$ Marxist intellectuals have been involved in these debates, focusing on the issues of national character, social content, and class affiliation of ethnic musical styles. During the late 1930s in the US, left-wing intellectuals were caught up in the debates of the popular front movement, which concerned national identity and the role of black and rural traditions in the creation of a new national popular culture. The debate was characterized by the ideas of nationalist Marxism and populism and was similar to the Left Greek discourse on rebetika, which also used the creative people as an effective revolutionary symbol of the progressive movement. The demand for class and national consciousness-a collective identity-was expressed not only through political tracts but also through art, music, and ritual. ${ }^{32}$

Marxist policy makers in socialist countries tried to block capitalist musical influences and spur an educational system that produced socialist art. By the late 1930s, the Soviet Union was using music as a basic vehicle to enhance the class consciousness of the proletarian according to the dogma of socialist realism instigated by Stalin's friend and cultural commissar Andrei Zhdanov. This dogma was developed to oppose the abstraction of modern art and to promote realistic representation of the new socialistic man in an idealized social environment characterized by equality and prosperity. ${ }^{33}$

More recently, Cuba's government supported traditional music and dance, encouraged new kinds of performances, and exhorted artists to think about their socialist society and write or sing in a way that reflected its values. ${ }^{34}$ In his insightful study, Robin Moore points out the ways in which the regime changed the country's rich musical traditions. Despite the rhetoric of the state regime, which insisted on the need to provide cultural and spiritual uplift to the masses, it used popular music as a vehicle for propaganda and even for the promotion of its tourist policy. The government had to block the connections of Triba with prostitution, the underworld, and black urban youth subculture in order to transform it into the pure song of the national proletariat. Also, Vincenzo Perna's class-study analysis shows the connections between culture and politics during the Cuban crisis period of the 1990s, when the regime exerted effort to control, often with repressive measures, the popularity of provocative and sensual songs. These songs

\footnotetext{
${ }^{28}$ Timothy Mitchell, Flamenco deep song (New Haven: Yale University Press, 1994).

${ }^{29}$ See, William Washabaugh, Flamenco: passion, politics and popular music (Oxford: Berg, 1996).

${ }^{30}$ Washabaugh, Flamenco: passion, politics and popular music; DaCosta Holton, "Like blood in your mouth," 309.

${ }^{31}$ Manuel, Popular music of the non-western world, 61.

${ }^{32}$ Ron Eyerman and Andrew Jamison, Music and social movements: mobilizing traditions in the twentieth century (Cambridge: Cambridge University Press, 1998), 65. Compare with, Robbie Lieberman, 'My song is my weapon' People's songs, American communism, and the politics of culture 1930-1950 (Urbana: University of Illinois Press, 1995), 34.

${ }^{33}$ Robin Moore, Music and revolution: cultural changes in socialist Cuba (music of the Africa diaspora), (Berkeley: University of California Press, 2006), 15.

${ }^{34}$ ibid., 24.
} 
reflected the contradictions of contemporary Cuba and frequently challenged official discourse on race, religion, gender, and political ideology. ${ }^{35}$

In capitalist countries, Marxism has used popular and youth music to "transform resistance into rebellion" and strengthen the class-conscious political goals in the struggle for hegemony. ${ }^{36}$ Marxist policy strategies aimed to create a space for resistance in the face of a capitalistic music industry. ${ }^{37}$

Marxist philosophy advocated the creation of a militant art that glorified the spirit of a socialist society that had yet to emerge, an art that would facilitate the task of educating workers in the ideals and meaning of socialism. From this point of view, art and politics were considered to have the same goals: "the betterment of society, the establishment of moral guidelines." 38 Progressive intellectuals had the task of forming a proletarian-national culture that included popular song, blocking alien imperialist influences, and inspiring "music in more utopian worlds." 39 The goal was to produce, in Mao Tse-Tung's words, "works which awaken the masses, fire them with enthusiasm and impel them to unite and struggle to transform their environment." 40

\section{Greek leftist discourse on rebetika: Between the oriental and occidental aspects of Hellenism}

Music is often claimed to be a primary defining feature of Greek culture. ${ }^{41}$ As a result, there was a certain inevitability to rebetika figuring in a debate about national identity. Greek nationalist ideology envisioned a community with cultural continuity that stretched back to the glorious past of classical Greek civilization, more or less uninterrupted. Within this ideological framework, nationalists tried to define the authentic cultural elements that reflected the noble Greek psyche and could serve as the basis for an ideal national identity, excluding any undesirable foreign influence.

The interest of Left-wing intellectuals in popular music dates back to the mid-1930s, when the organization of the Soviet Union writers initiated the dogma of socialist realism. Since the emphasis on popular traditions was a main principle of this theory, the question of what was authentic popular music attracted the interest of Marxist writers. In the post World War II era, rebetika song received special attention from Leftist scholars, artists, writers, and journalists. According to Marxist intellectuals, popular music was expected to express the deeper social needs, feelings, and hopes of the militant proletarians and the virtuous "inner self" of the nation. In this way, the nostalgic attitude towards the romanticized traditions of the nation overlapped with the political goal of creating a noble type of popular song with a social content that bespoke the valour of the proletariat.

The Left-wing writers that engaged in the discourse about rebetika were middle-class. They were interested in the cultural and political significance of art, particularly music; and they attempted to interpret rebetika employing a Marxist-influenced analytical framework. They functioned as an avant-garde within the progressive movement, playing active political roles in the apparatus and the organizations of

\footnotetext{
${ }^{35}$ Vincenzo Perna, Timba: The sound of the Cuban crisis (Ashgate: London and Burlington, 2005).

${ }^{36}$ See Paul Corringan and Simon Frith, "The politics of youth culture," in Resistance through rituals, Youth subcultures in postwar Britain, ed. Stuart Hall and Tony Jefferson (London: Routledge, 1975), 238.

${ }^{37}$ Moore, Music and revolution: cultural changes in socialist Cuba, 1.

${ }^{38}$ ibid., 13.

${ }^{39}$ ibid., 1.

${ }^{40}$ Quoted in Robin Moore, Music and revolution: cultural changes in socialist Cuba, 13.

${ }^{41}$ Gauntlett, "Orpheus in the criminal underworld," 11.
} 
Left-wing political parties. Due to their political beliefs, the majority of them suffered persecution. Some had been exiled in remote islands after the Second World War due to their participation in the Civil War on the side of National Liberation Front (EAM); others were political prisoners during the years of the Greek dictatorship (1967-1974). Several Leftist thinkers were fascinated by the mystique of rebetika, but they were confronted with major challenges in reconciling their political ideals with their musical tastes.

Some of the Leftists engaged in the rebetika debate were professionals in the field of music. Among them were Mikis Theodorakis, (the eminent composer), Alekos Xenos (composer and policy-maker of National Popular Liberation Army/ELAS), Haris Xanthoudakis (composer), Foivos Anoyianakis (musicologist and music-critic), and Panos Tzavelas (exponent of many Guerilla revolutionary songs).

In addition, there were Marxist theoreticians and scholars who were interested in the co-opting culture for the benefit of subordinate classes in their political struggle against capitalistic forces. They believed that a better educated and class conscious proletariat could play a more prominent role in the struggle toward social transformation and saw music as pedagogically useful for inculcating class consciousness. ${ }^{42}$ This group included Nikos Poulatzas (eminent theoretician of the Left movement, political scientist, and sociologist at École des Études et Sciences Sociales), Stathis Damianakos (sociologist then at the Centre National des Recherches Scientifiques), Kostas Vergopoulos (sociologist and political scientist, later scholar at Universititè de Paris IVIII), Kostas Sofoulis (social scientist and later scholar), Tasos Vournas (historian, journalist, and litterateur), Nikos Politis (poet and litterateur), Zisis Skaros (novelist), Yiannis Skouriotis (author and the first translator of the Greek edition of Marx's Capital), and Evaggelos Machairas (lawyer and author).

Angela Shand, in her essay on identity, theology, and gender in rebetika, presents some of the binary schemes that were used by the eminent litterateur Nikos Kazantzakis to depict the double Greek identity: East-West, Romeic-Hellenic, female-male, body-mind, frivolous-serious, and sin-virtue. ${ }^{43}$ Despite the claims of Left-wing intellectuals that a Marxist analysis of culture should transgress the stereotypes of bourgeois and nationalist ideas, Leftist rebetologists fell into the trap of ethnocentric obsession by using various dualistic stereotypes in order to describe Greek culture.

The interwar period witnessed intense ideological and aesthetic explorations of the cultural identity of Greek society. During this era, many texts appeared in the press in Athens, Piraeus, ${ }^{44}$ and some provincial cities, such as Heracklion, ${ }^{45}$ focusing on the cultural value and national character of some musical styles, such as amanedes and disreputable songs. To some extent, this discourse on popular music was a continuation of an older debate between the proponents and the opponents of oriental music that dates back to the 1890 s. $^{46}$

The majority of the arguments challenged the cultural quality and the "Greekness" of this music, emphasizing the moral risks that came with their spread in respectable society. Apart from a few lukewarm and positive comments, the majority of the published opinions disapproved of the "shame" and the "filth" of amanedes." They were decried for their Anatolian "Arabian-Persian roots" and "barbaric music

\footnotetext{
42 Zaimakis, "Bawdy songs and virtuous politics," 15.

${ }^{43}$ Angela Shand, "Tsifte-teli sermon: identity, theology, and gender in rebetika," in The passion of music and dance: body, gender and sexuality, ed. William Washabaugh (Oxford: Berg, 1998), 129. Compare with Kazantzakis, fourney to the Morea, 167-8.

${ }^{44}$ See Gauntlett, "Orpheus in the criminal underworld" and Vlisidis, Aspects of rebetiko, 14-60.

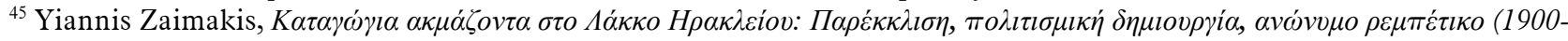
1940) [Flourishing dens in Lakkos of Heracklion: deviation, cultural creation, anonymous rebetiko (1900-1940)], (Athens: Plethron, 2008), 125-36.

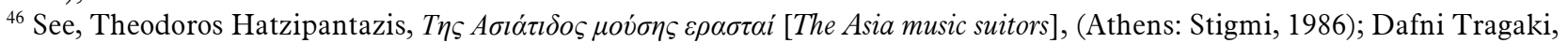
Rebetiko worlds (Cambridge: Cambridge Scholars Publishing, 2005), 5-10.
} 
harmony," ${ }^{47}$ condemned as the effluence of another country that had washed up on the shores of Greece. Other critics who held similar opinions also felt that national music was disappearing, and demanded that, 'in the name of the Greek soul and aesthetic,' amanedes should be banned. ${ }^{48}$

In the inter-war literature, as Gauntlett shows, one finds a number of texts by well-known writers, some of them being Leftists (for example Pikros, Varnalis) on the subject of rebetika. These writers engaged with the low-brow genre and borrowed the "lumpen-language" argot, colouring their works with satirical depictions of the Greek marginal world. ${ }^{49}$ As Gauntlett notes, inter-war Greek literature had "a modest and largely indirect contribution to the long-term construction of rebetika as genre, by signalling its existence (albeit by other names), creating a mystique around its performance context and, at a safe distance, cultivating awareness of its myths, forms and idiom (albeit in a negative or parodic vein). ${ }^{n 0}$

Special attention to the national qualities of popular music within the Marxist intelligentsia seems to have been reinforced with the rise of fascist regimes in European countries. It was under these circumstances that the $7^{\text {th }}$ Conference of the Communist International (1935) decided to form anti-fascist blocks all around the world. Following the recommendations of the Conference, the Greek Communist Party overhauled their politics, which was previously based on the principle of class struggle, and turned towards the constitution of a Front of National Unity. The idea was to foster international cooperation to defeat the imperialist and fascist forces.

During this period, Marxist intellectuals systematically elaborated the ways in which a national literature and art could be significant for the construction of a socialist society. As a consequence, the struggle for proletarian song was coupled with the romantic idea of seeking a national music that would continue the longstanding heroic and noble traditions of the nation, particularly the magnificent cultural traditions of subordinated classes. If such a music could be found, it would stand apart from the hegemonic system of habits, tastes, and beliefs of the ruling classes, which amounted to (so these writers believed) an uncritical acceptance or imitation of the western elites' cultural preferences and practices and was thus not appropriate for national representation. This line of argumentation was advanced by the folklorists of many countries and across the whole political spectrum, as they attempted to negotiate and create a new national-cultural identity through "the re-animation of the heroic past and certain idealized popular social and cultural products." 51

Leftist intellectuals turned their attention back to the roots of Greek history in order to point out the continuity and the liberating forces of the "authentic" popular traditions inspired by the epic struggles of Byzantium era, the War of Independence, and the rich regional folk traditions of race. All these considerations reflected notions of Hellenism. They were based on continuity and on a pure national identity and not on the heterogeneity or the syncretic aspects of Greek culture. ${ }^{52}$ The use of heroic elements derived from nostalgia for the cultural traditions of the past that, in turn, could be used by Marxist artists as archetypal patterns in their effort to create "pure" popular art music. This music was expected to be a grassroots expression, inspired and created by the people according to the Marxist ideal of a utopian society in which there would be many more artists from the lowest social strata developing their

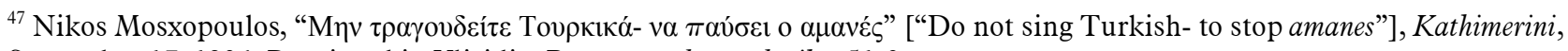
September 17, 1936. Reprinted in Vlisidis, Rare texts about rebetiko, 51-2.

${ }^{48}$ Anonymous article on “A $\mu \alpha v \varepsilon ́ \delta \varepsilon \zeta »[$ Amanedes], Idi (Heraclion), November 24, 1935.

${ }^{49}$ Gauntlett, "Rebetika and inter-war literature," 89-101.

50 ibid., 99-100.

${ }^{51}$ Steingress, "The comparative history of flamenco, tango, and rebetika," 163.

${ }^{52}$ Dimitris Tziovas, "Beyond the Acropolis: Rethinking Neohellenism,” Fournal of Modern Greek Studies 19 (2001): 203.
} 
creative potential rather than a few professionals. Thus, the socialist-inspired authors of that time tried to put the communist slogan "art from the people and for the people" into action. ${ }^{53}$

The period of Metaxas's dictatorship was characterized by extensive intervention of the regime in Greek society, the goal being the spread of its own particular national ideals. It fostered an intensely authoritarian, chauvinistic, and populist environment, ${ }^{54}$ in which the Greekness of cultural creations became an important topic. The regime's efforts to cleanse society from its polluting forces were part of a vain plan to construct a modern glorious "third civilization" on a par with the Ancient and Byzantine past.

During this time, many people who were branded a "danger to the public" and condemned for behaving immorally or living a troubled life suffered the devastating experience of exile to desolate islands. Areas known to be frequented by prostitutes were subjected to strict surveillance and many local manghes were sent to exile in remote parts of the country. ${ }^{55}$ Cultural creation, especially record production, fell under the systematic control and censorship of the repressive and ideological state apparatus. ${ }^{56}$ The main objective of the state censorship was the protection of society from a twofold threat: the songs including immoral verses or phrases which "offended against the religion and the common respectabilities" and "anachronistic songs," ${ }^{57}$ mainly amanedes that, due to their Anatolian origin, did not conform to the State's ideals of a pure Greek civilization.

The Right-wing press welcomed the censorship measures against "amanedes, dervish and Asikis songs," favoring the westernization and modernization of Greek national identity and the purging of all "sinful Anatolian" elements. ${ }^{58}$ On the Left, the issue of Greekness appeared clearly in the post war era among some opponents of rebetika who stressed the eastern origins of the genre and argued that it should be disentangled from the pure traditions of Greek music. In this way, Xenos criticized the genre's origin in the "melodic remnants of the Turkish conqueror" that were brought by the newly immigrated refugees during the exchange of population between Greece and Turkey. In his binary scheme, languorous rebetika were placed opposite to the tradition of the dimotiko (folk song), which was identified with the "kind" and heroic tradition of Hellenism. ${ }^{59}$ Similarly, Papadimitriou disdained eastern elements of the genre-the "heavy Anatolian colour" of the melodies and certain types of dances and instruments—arguing that they "have no connection with the music of enslaved Hellenism." 60

The alleged oriental melancholic tones and the sense of fatalism of the genre were viewed by dogmatic Left-wing intellectuals as decadent elements that could not accommodate the ideals of the patriot and the optimistic perspective of the Left movement. It is obvious that the signs of heterogeneity in rebetiko suggest a diverse Greek identity that stands in contradistinction to ethnocentric beliefs that insist on the unbroken continuity of the nation. As Holst-Warhaft notes, "despite the successful propagation of the myth of cultural continuity, Greeks continued to insist on a model of community-based affiliation that was at variance with official ideology and frequently crossed linguistic and ethnic boundaries." They

\footnotetext{
${ }^{53}$ Ntounia, Politics and Literature, 436.

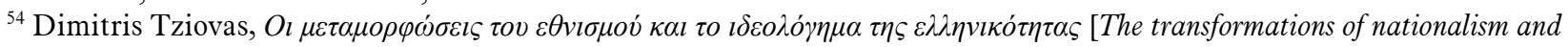
the ideology of Hellenism], (Athens: Odyseas, 1989), 152.

${ }^{55}$ Zaimakis, [Flourishing dens in Lakkos of Heracklion (1900-1940)], 125-36.

${ }^{56}$ Vlisidis, Aspects of rebetiko, 25-61; Pisto Pekka Pennanen, "Greek music under the dictatorship of General Ioannis Metaxas" (1936-1940), Grapta Poikila I (Helsinki: Papers and monographs of the Finnish Institute in Athens, VIII, 2003): 119-122.

${ }^{57}$ Anonymous article on “Oı $\alpha \mu \alpha v \varepsilon ́ \delta \varepsilon \varsigma$ " [“Oi amanedhes”], Ethnos, November 30, 1937.

${ }^{58}$ See Vlisidis, Aspects of rebetiko, 14-60 and Zaimakis, [Flourishing dens in Lakkos of Heracklion], 140-154.

${ }^{59}$ In Xenos's text titled “E $\pi \iota \tau \tau$ ג

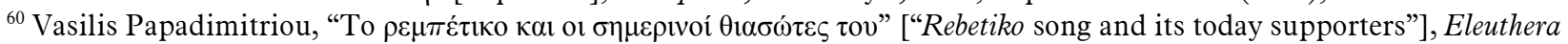
Grammata 1-2 (1949): 48-52; Reprinted in Holst (1991): 145-151.
} 
usually "embraced a superficial vision of themselves as members of a nation while defining themselves through songs as inhabitants of a subgroup that transgresses, in more respects, the boundaries and/or ideals of the state." ${ }^{61}$

Other intellectuals examined the national traits of rebetika utilizing evolutionary schemes. Among the well-known representatives of this approach was Mikis Theodorakis, a Left-wing composer who was educated in western classical music and later wrote "music for the masses." According to Theodorakis' view, music should have some sort of political orientation and national popular music ought to play a vital role, fostering national cohesion and promoting the cultural uprising of the working class. With regards to rebetika, he argued that the genre could not become the music of working Greeks and would not progress from its state of disrepute. For this reason, he proposed the creation of a higher, national form of popular song and the cleansing of rebetika from its unhealthy, impure elements, namely the Anatolian associations, Turkish motifs and melodies, and underworld themes. ${ }^{62}$

In the Left reformist magazine Anti, Xanthudakis argued that the genre had evolved, the undesirable oriental elements falling away. He conceded that the genre in the early phase of its development was an amalgam of western and eastern elements, but that it later cast off Anatolian characteristics in favour of modern European musical motifs. This change took place in parallel to a social transformation in which the social bearer of rebetiko, the lumpen-proletariat, was gradually incorporated in the working class. ${ }^{63}$ Seen from this perspective, the gradual westernization and modernization of the genre in conjunction with the cleansing of its disreputable associations were perceived as substantial proofs of its aesthetic and musical transformation. Xanthoudakis's dualistic scheme, establishing a dichotomy between old, unsavoury, and oriental aspects of rebetika and their westernized and progressive traits reflected the distinction between, in Tziovas' terms, European rationalism and Hellenism on the one hand, and oriental indiscipline and backwardness of the nation, on the other. ${ }^{64}$

In 1975, Nikos Poulantzas intervened in the debate on popular culture, vocally demanding the formation of a popular-national unity in order to block the all-pervading forces of cultural imperialism. In a series of articles in Nea, ${ }^{65}$ Poulatzas criticized the prevalent Orthodox Marxist thesis that the progressive movement had to create a type of militant popular art based on the principles of proletarian internationalism and communist purity. Although he appeared to castigate those who dogmatically rejected rebetiko, particularly the leadership of the Greek Communist Party (KKE), ${ }^{66}$ he agreed with some of their ideas. For instance, he found bourgeois influences in some rebetika, pointing specifically to the low status of women as portrayed in the lyrics. Thus, rebetika perpetuated, and possibly exacerbated, the subjugation of women to men in capitalist society. ${ }^{67}$

\footnotetext{
${ }^{61}$ Gail Holst-Warhaft, "Whither the Neohellenic? Song, Self-identity and the Neohellenic," Fournal of Modern Greek Studies 15, no. 2 (1997): 232.

${ }^{62}$ Mikis Theodorakis, Star system (Athens: Kaktos, 1984): 68-75.

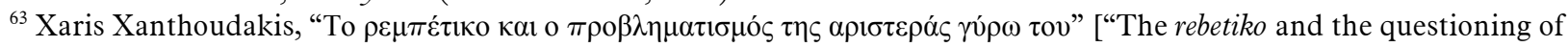
Left about it"], Anti 13 (1975): 47-48.

${ }^{64}$ Dimitris Tziovas, "Beyond the Acropolis: Rethinking Neohellenism,” 200.

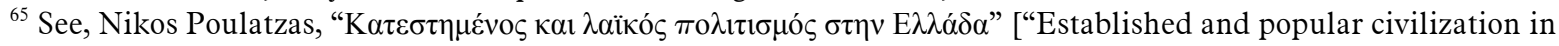

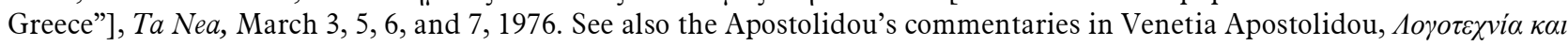

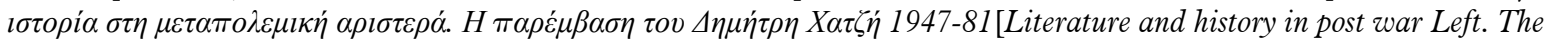
intervention of Dimitris Hatzis 1947-1981], (Athens: Polis, 2003), 257-60.

${ }^{66}$ Poulatzas, "Established and popular civilization in Greece," Ta Nea, March 6, 1976.

67 ibid.
} 
Regarding the issue of the expression of Greekness in art, Poulatzas disagreed with the bourgeois perception of Hellenism, which according to his argument, imitated and reproduced the western scholar's folklorist or classicist reflections of Greek civilization. At the same time, he denounced the populism of those who venerated the alleged "purity and virginity" of the people's culture, noting that the dominant culture infiltrated the body of popular cultures, spreading its corrupted influences throughout all social strata. Despite these alien influences, the cultures of subordinate classes were thought to have, to some extent, authentic and liberating elements and a hidden subversive spirit. ${ }^{68}$

The vision of Poulatzas was the creation of an authentic Greek civilization, a cultural utopia inspired by the traditions of the under-privileged classes. His 'imagined community,' to use Damianakos's designation, would be informed by what he perceived as a long-standing tradition of revolt amongst the social classes evident in rebetika, cleftika, brigand's songs, and the Greek Shadow Theater (Karagiozis). ${ }^{69}$ Poulatzas proposed the formation of a progressive cultural movement through the close cooperation of the Leftist avant-garde and the mobilized proletariat. He also supported the nostalgic "return to roots," expecting to bring to light alleged resistant elements in the traditions of under-privileged classes, incorporating them in a modern counter-hegemonic class culture.

Poulatzas's reformist view replaced Orthodox demands for a militant and "pure" popular art guided by the ideals of the Communist Party's bureaucratic elite with the more moderate idea of forming a counter-culture associated with a massive, grassroots cultural movement. Poulatzas's conceptual scheme concerning the basic analytic distinction between the "respectable" and "unsavoury" (subversive) sides of popular culture seems to have influenced many Leftist rebetologists engaging in the relevant discourse.

Some anxious patriots, sympathizers of the genre, attempted to locate the origins of some elements for instance, dance forms and musical instruments - in the remote past of nation. They were inspired by the romantic idea of seeking a new national identity based on certain idealized social and cultural patterns derived from a nostalgic heroic past. ${ }^{70}$ In pursuing this idea, they relocated the origins of the genre in a heroic period of Hellenism and asserted its essential purity and Greekness. For example, the roots of rebetiko style and motifs were located in the Byzantine era and old Ionia from which they were transmitted to the Greek mainland, by refugees from Asia Minor; and there they were fused with the indigenous maghika generating the rebetika. ${ }^{71}$

Similarly, in the analysis of historian Tasos Vournas, certain allegedly-pure Hellenic elements of rebetika were adopted as traces of noble tribal characteristics, while older traits of Turkish origin were described as the undesirable residue of the Ottoman occupation. He used historical evidence (for instance the use of the tabouras, an ancestor of bouzouki, by eminent fighters of the Greek National Revolution in 1821) in order to support the rather vague claim that the bouzouki, the most important musical instrument of the rebetes, was connected to the heroic traditions of Greeks. Moreover, he claimed that rebetika melody had at its initial stages an obvious Anatolian colour that increasingly incorporated elements deriving from

\footnotetext{
${ }^{68}$ Poulatzas, "Established and popular civilization in Greece," Ta Nea, March 3 and 6, 1976.

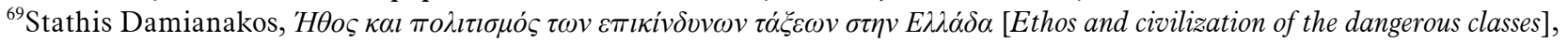

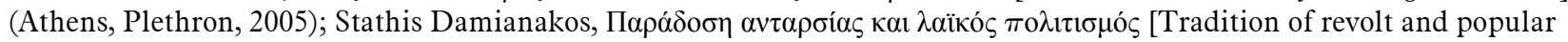
civilization], (Athens, Plethron 1987). See also Benedict Anderson, Imagined communities: reflections on the origin and spread of nationalism (New York: Verso, 1991).

${ }^{70}$ Steingress, "The comparative history of flamenco, tango, and rebetika," 163.

${ }^{71}$ Kostas Sofoulis, "Epistoli” ["Letters"], Epitheorisi Tehnis 20 (1956): 153; reprinted in Vlisidis, Rare texts about rebetiko, 222225.
} 
Byzantine chants, folk agrarian culture, the music of the Greek islands, and the tradition of cantata. ${ }^{72}$ The genre's supposed connection with the noble Romaic psyche and "upstandingness" was presented as substantial proof of a "pure" cultural product that reflected the imagined qualities of the Greek nationwhat many folklorists and artists called romiosini. ${ }^{73}$

In the same spirit, Foivos Anoyianakis traces the rebetiko origins back to the glorious past of romiosini, which extends both to the old Pre-Hellenic ancient civilizations of the Eastern world and to the music of Ancient and Byzantine times of Hellenism, by quoting historical texts and pointing to gravures of musicians holding instruments reminiscent of rebetika. The latter were perceived as documents of the cultural continuity of the nation. He also substantiates the syncretic nature of musical crossbreeding in rebetiko claiming that it was the result of fusion among "the older Greek popular song, Byzantine melody, and the Eastern popular song." 74

Other writings marked by a spirit of Romanticism examined the morphological characteristics of rebetika songs in relation to the alleged eternal anthropological virtues of Greek people. In his article in $A v g i$, Kostas Vergopoulos presents a romanticized picture of rebetiko as an authentic expression of Greek cultural civilization, merging "Dionysian elements from ancient Greece, mysticism from Byzantium, and 'Dervishika' traits deriving from the Ottoman period," all identified with the Orient and contrasted with the incursions of Anglo-American western culture. ${ }^{75}$ From a historical point of view, he saw a connection between the lumpen-proletariat and the "persecuted Greek tradition" as working against the increasing impositions of westernization. According to this argument, "the history of the modern Greek state is the history of the marginalization of the Greek popular tradition in favor of a formalistic westernization under the pretext of veneration of the Greek antiquity." The author claims that various musical elements originating from the Byzantine and Ottoman periods, bearing traces of nobility and patriotism, were omitted as Oriental creations. Having found in rebetika a subversive spirit of the Greek soul and the Dionysian elements of the hidden, Eastern aspects of Hellenism, the author characterized them as a high art expression of Modern Greece, parallel to Papadiamantis's fiction and Cavafy's non-conformist poetry.

In contrast to Vergopoulos's ideas about the marginal and oriental character of rebetika, his comrade Kounadis claimed that a phenomenon of popular culture should not be studied in the context of a concrete historical era away from long-standing popular traditions and cultural continuities of a society. He stressed the need for a systematic approach of the genre, taking into account the "national, racial and cultural unity of Greekness."76 This view reflects a current of thought within the Left intelligentsia imbued by the familiar, romantic idea of the uncorrupted continuity of Greek civilization.

In conclusion, Marxist discourse seems to introduce into the debate on Greek identity a new binary scheme of Hellenism concerning the distinction between the noble and gentle heritage of subordinate classes and the bourgeois culture of a hegemonic system of habits and beliefs. However, this Marxist influenced dualistic scheme was permeated by nationalistic ideas and, as a result, their application led to ambivalent and vague arguments concerning the cultural and historical associations of rebetika.

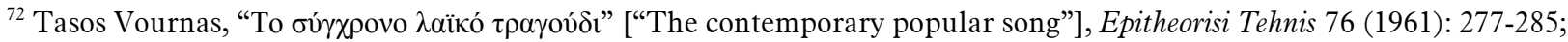
reprinted in Gail Holst-Warhaft (1991), 164-185.

73 Tragaki, "Humanizing the masses," 58.

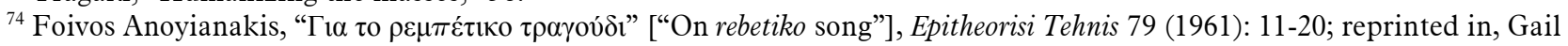
Holst- Warhaft, [1991], 184-200).

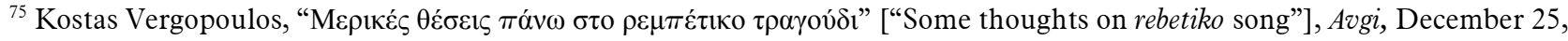
1974; reprinted in Holst (1991), 231-237.

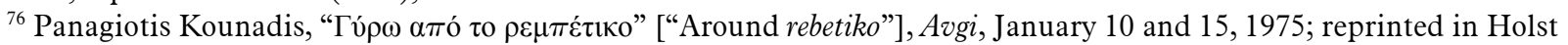
(1991), 242-3.
} 
Both the champions and opponents of rebetika used selective historical documents and cultural elements in order to evaluate the genre and to emphasize either its association with the cultural continuity of the nation or its alien nature. Indeed, the Eastern and Turkish associations of rebetika were perceived as reflections of the national decadence and humiliation occasioned by the Ottoman occupation; ${ }^{77}$ connections with the glorious era of Hellenic civilization (Byzantine and ancient times) were regarded as signs of a musical superiority compatible with the noble traits of the race. Nevertheless, some writers projected on rebetika an exotic and romantic picture and find in them reflections of the mystical Eastern side of Hellenism, an identity based on the Romaic passion of the magnificent Orient as opposed to European rationalism.

Generally, Leftist rebetologists met with grave difficulties in their attempt to apply their theoretical schemes to the peculiar case of rebetiko. It was an intercultural musical genre that included various musical elements derived, according to Streigness, from the cosmopolitan popular traditions of Ottoman millet, the tense dialectic relation of music from Asia Minor and continental marginal music, as well as Turkish and Greek culture. ${ }^{78}$ These attitudes of Greeks to their popular music reflect, to a point, what Gail HolstWarhaft defines as the "double-descended" character of Greekness, ${ }^{79}$ the country's peculiar position between Orient and Occident, eastern Orthodox Christianity and the European secular tradition, or more simply between Asia Minor and Europe. ${ }^{80}$

\section{The discourse of "purity" and popular song}

According to Marxist thought, the form and content of art were political issues. Popular art and music were expected to be used as a pedagogic means for inculcating class consciousness in the working people. The ideal form of socialistic music is one that contains a politicized message and supports the liberation of humanity. ${ }^{81}$ Thus, it was a main political duty for the progressive avant-garde to foster a kind of militant popular song that offered the proletariat the chance to explore art, stimulated class consciousness, and boosted communist morale. Members of the avant-garde aspired to create spaces of resistance that would mitigate the stultification and alienation of the proletariat fostered by immoral, vulgar, or a-political songs. Equipped with these politically motivated objectives, the Marxist intelligentsia attempted to evaluate the morphological characteristics of the genre of the rebetika and to examine whether it was a form of a pure, social popular song or whether it was a polluted cultural product that diverted the proletariat from political activity.

Throughout the post war era, in the columns of Left-wing newspapers and journals, writers posed questions about the class orientation of rebetika. Also, they attempted to define the terms rebetika and laika (popular) songs, although their definitions were often vague, a function of their political aspirations rather than the desire to provide an accurate analytical description. Indeed, the term laiko is often used as an

\footnotetext{
${ }^{77}$ Michael, "Tsitsanis and the birth of the 'new' laiko tragoudi," 85.

${ }^{78}$ Streigness, "The comparative history of flamenco, tango, and rebetika," 162. See also Koglin, "Marginality-A key concept to understanding the resurgence of rebetiko in Turkey," Music and Politics 2, no. 1 (2008): 3-13.

${ }^{79}$ See Holst- Warhaft, "The double-descended character of the deep songs of Greece," 113-115.

${ }^{80}$ Holst-Warhaft, "World music and the orientalising of the rebetika," Hydra Rebetiko Conference 2001, www.geocities.com/hydragathering/holst3.html (Accessed 07/04/03).

${ }^{81}$ See Moore, Music and Revolution, 13.
} 
evaluative conceptual scheme that refers to an idealized, nobler form of song expressing the "real" desires, hopes, and torments of working people, the means of disseminating an optimistic, militant spirit to the subjugated. ${ }^{82}$

In the camp of those opposed to rebetika, many intellectuals invoked moral and aesthetic judgments to substantiate claims about the alleged anti-social character of rebetika. For the majority of them, the unhealthy facets functioned as a kind of symbolic pollution. According to Douglas, the pollution beliefs refer to the kind of contacts that are considered dangerous and carry a symbolic load. Some types of pollution are used as analogies to express a general view of the social order. The idea of dirt in Douglas's work refers to "matter out of place." It implies two conditions: a set of ordered relations and a contravention of this order. "Dirt is the by-product of a systematic ordering and classification of matter, in so far as ordering involves rejecting inappropriate elements. This idea of dirt takes us straight into the field of symbolism and promises a link-up with more obviously symbolic systems of purity." Pollution behavior is the reaction that condemns any object or idea likely to confuse or contradict cherished classifications. ${ }^{83}$

Marxists defined the canon of militant art as being defined by the accepted tastes of fighting workers. According to communist doctrine, responsible artists, including songwriters, should interpret the social reality from a Marxist point of view in order to promote the deterministic revolutionary process that would lead to a utopian future. Since musicians and composers were said to be vehicles of proletarian culture, they should combine, as Zhdanov stipulated, their need for artistic expression with the political task of the ideological reformation and education of working people in the spirit of socialism. ${ }^{84}$

In discourse about rebetika, the ideal of a social-popular song full of optimism and militant consciousness is connected with the idea of a moral and political order compatible with Marxist conduct and habits. Using logic that rested on binary stereotypes, symbolism, and metaphors, Marxist opinion leaders presented a conceptual scheme that contrasted the order of an ideal proletarian system of habits and values on the one hand, with the disordered situation and the symbolic pollution of capitalist society, on the other. According to Douglas, "the discourse of purity and impurity creates unity in experience (and thought). Symbolic patterns are worked out and are publicly displayed. Within these patterns, disparate elements are related and disparate experience is given meaning." Pollution ideas work in the life of society as people trying to influence one another's behaviour reinforce social pressures and political conformism. ${ }^{85}$

Christina Ntounia, in her work on Marxist literacy in the interwar era, presents a scheme of dichotomies that was used by the authors of the Marxist magazine Neoi Protoporoi. The scheme mirrors the most important differences between the aesthetic and political principles of socialist realism in art and the canons of bourgeois naturalism, i.e., the hegemonic cultural order of ruling classes.

\footnotetext{
${ }^{82}$ Michael, "Tsitsanis and the birth of the "new' laiko tragoudi," 64.

${ }^{83}$ Mary Douglas, Purity and Danger: an Analysis of the Concepts of Pollution and Taboo (Routledge, London \& New York: Routledge [1993 (1966)], 4, 7, 35-6.

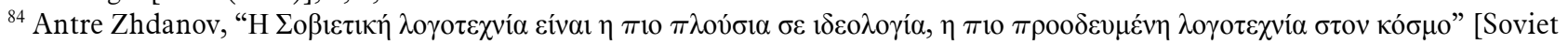

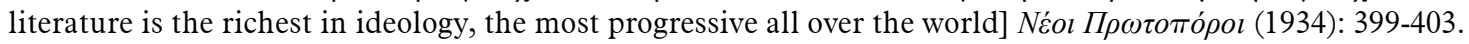

${ }^{85}$ Douglas, Purity and Danger: an Analysis of the Concepts of Pollution and Taboo, 2-3.
} 


\begin{tabular}{|c|c|}
\hline Naturalism & Socialist Realism \\
\hline particularity & entirety \\
\hline description of misery & bring to light the reasons of misery \\
\hline bourgeois decadence & socialistic perspective \\
\hline pessimism & optimism \\
\hline abandonment & fight \\
\hline stalemate & revolutionary solution ${ }^{86}$ \\
\hline
\end{tabular}

Marxist artists and composers were expected to create optimistic, popular songs expressing the needs, dreams, sorrows, and pains of the downtrodden and spreading an aggressive, political spirit. Proletarians should demonstrate a Marxist view of daily life, and popular song ought to reinforce the communist moral order by presenting pictures full of optimism and proletarian militancy. Musical performances ought to create a form of resistance against the pessimistic, abstract, and decadent cultural products that were promoted by the capitalist entertainment industry.

In general terms, the majority of Marxist rebetologists and the Communist leadership rejected rebetika, characterizing them as apolitical, lascivious songs that spread the spirit of immoral individualism, hedonism, and fatalism within society. Therefore they constituted a pollutant force in the service of dominant ideology. Some other Leftist intellectuals tried to reconcile the charm of rebetika with their political ideology, presenting moderate, often ambivalent, evaluations of the genre. ${ }^{87}$

One of the well-known representatives of anti-rebetiko discourse was the composer Alekos Xenos, who argued, in an analysis centred on class, that rebetika promoted drugs and pornography, and that they grew out of a diseased social atmosphere, becoming a vehicle of elements most detrimental to popular traditions. According to his vague explanation, the influence of rebetika in society expanded from the sordid lumpen-proletariat, born amidst the pressure of the plutocratic economic policy to a decadent part of the upper class. ${ }^{88}$ Later, he expanded his argument regarding rebetiko, characterizing it as the music of underworld and not of the people. He condemned its "low spiritual and emotional content" that led the proletariat to a state of degradation, and "absolute nihilism" without intellectual uplift, perspective, and ideals. $^{89}$

Vasilis Papadimitriou also made a generic distinction between ideal "authentic popular" songs and the fashionable pseudo-laika and the immoral drug-promoting and pornographic rebetika songs. In his opinion, rebetiko was the music of the social groups that frequented "the hashish dens and café-santan around the brothels of Troumpa" and thus they were not considered to have any relation with respectable working people. Since rebetika mirrored the "putridity of the underworld," it was a song of escape from reality, and, on the political level, it expressed the decline and fatalism of the more reactionary strata of Greek society. ${ }^{90}$

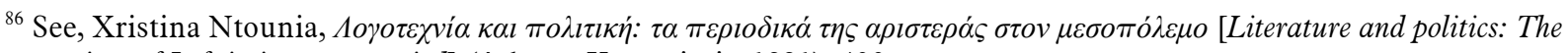
magazines of Left in interwar period] (Athens: Kastaniotis, 1991), 400.

${ }^{87}$ For a detailed presentation of the controversial argumentation of Left-wing writers on rebetiko song, see Vlisidis, Aspects of rebetiko, 69-164.

${ }^{88}$ Xenos' letter to Rizospastis, February 23, 1947; reprinted in Holst, Road to rebetiko, 141-2.

${ }^{89}$ Xenos letter to Avgi, March 23, 1961.

${ }^{90}$ Papadimitriou, "Rebetiko song and its today supporters," 148-9.
} 
Another explanatory scheme used in anti-rebetika discourse was based on the distinction between the "salubrious" and the "unhealthy" side of people. From this perspective, the pure popular song reflects the "virtues of our people, kindness of soul and love for life," while rebetika mirrored the "weak side of the popular heart": it easily accepted the spirit of pessimism, especially in periods of social crisis, (for instance, the years after Greek Civil War era where "fatalism, discouragement, and decadence" had been cultivated within the masses).${ }^{91}$ Dealing with drug-related and other distasteful themes, the genre was perceived as a phenomenon outside the communist value system. Far away from the communist realm of social struggle, the characters of rebetiko dwelt in the darkness of the underworld, full of "misery and tiredness," playing "cheap and ribald" music. ${ }^{92}$

Still another negative assessment of rebetika focused on the alleged low qualities of the genreelements that were considered a distortion of musical tastes and moral principles of the working people. Using a rhetoric marked by the ideas of symbolic pollution, writers described rebetika as "obscene, immoral, dirty and anti-aesthetic creations" growing out of the "social rot" of our society and polluting the proletariat. ${ }^{93}$ Melodic lines were rejected because of their sad and pessimistic style, which inspired "despair, lamentation, and destructiveness," instead of calling people to "praise a life of dignity and struggle." 94 The song lyrics, also, were said to promote an individualistic and pessimistic way of thinking, the expression of disappointed people without faith in any collective idea and in a better world deploring the subordination of masses to fate and destiny. ${ }^{95}$

Using the familiar argument about rebetika's association with the underworld, Leonidas Piroudis, a political prisoner during the years of Junta dictatorship, challenged the popular orientation of rebetika through the illegal magazine Tetradia. He emphasized his criticism toward the hashish songs, which were a foreign body in the real popular song due to their low aesthetic and their connection with the "ill circles" of the underworld. According to Piroudis, the antisocial traits of rebetika were an obstacle in the fight of the progressive movement for freedom and democracy. ${ }^{96}$ Rebetika facilitated the aims of the reactionary forces by contributing to the torpor and the political disorientation of the masses.

Some opinion leaders among rebetika sympathizers, challenged the dogmatism of their opponents, contending that rebetika had artistic value and that it had social significance as a means of expression for the lower social strata. During the Junta of the Colonels, some reformist Leftist intellectuals espoused a more qualified critical view. Criticizing the polemic stance of respectable society (including its Left-wing representatives) against rebetika, Yiannis Kaounis described rebetika as a type of song that expressed the daily yearnings of the poor in urban neighborhoods and harbors. Although he subscribed to the common assessment of hashish-related songs as a "psychological outlet for uneducated and unemployed members

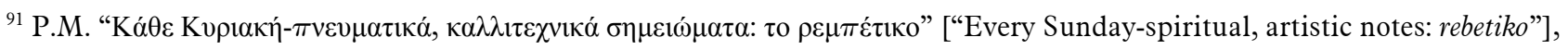
Avgi, August 20, 1953.

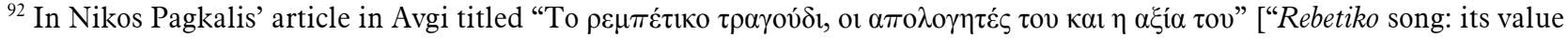
and the song's apologists"], Avgi, February 14, 1953; reprinted in Vlisidis (2005), 182-3.

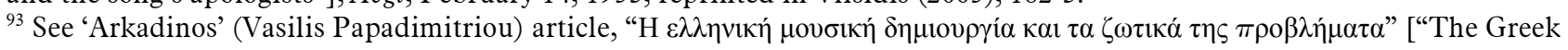
musical creation and its vital problems"], Avgi, September 23, 1959.

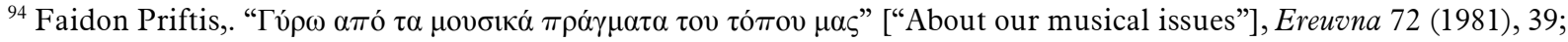

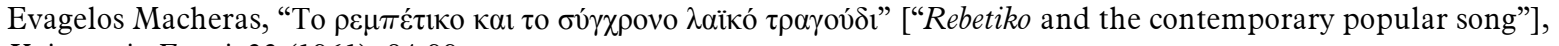
Kainourgia Epoxi 22 (1961): 84-99.

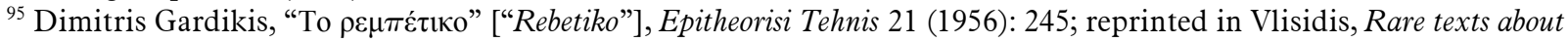
rebetiko, 226.

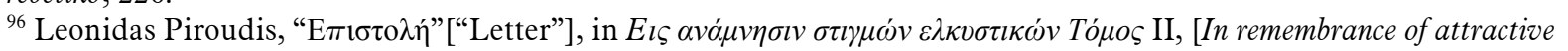
moments, vol. II], (Athens, 2003), 497-9. (First publication in manuscript on Tetradia 6, 1970.)
} 
of the proletariat," unlike other voices, he regarded them as an old, oral tradition of songs valued and accepted by people. Consequently, he saw rebetika as an organic part of popular music. ${ }^{97}$

Panos Tzavelas claimed that rebetika were created in hashish dens, slums, and prisons by the victims of society, "the wretched proletarians amidst the hell and horror of the social gutter." He saw in songs about hashish a social indicator of the miserable living conditions of the lumpen social strata, noting that although the texts were not acceptable in modern context, they were in fact an artistic expression of a part of the social reality of the past. As a result, rebetika showed the stages that the proletarian consciousness followed until it understood that the solution to issues of social injustice is not an escape into ephemeral pleasures, like the use of hashish, but revolutionary social change. He criticized not only the negative labelling of rebetika by the upper class, but also the inability of the progressive movement to evaluate objectively the musical value of hashish songs, thus pointing out that the negative stance of the bourgeoisie and the Left rested on the same argument. ${ }^{98}$

In the spirit of these reformist evaluations, other commentators described rebetika as a pure popular music with social, and often political, content, and sometimes used the terms rebetika and laiko interchangeably. For instance, the scholar Sofoulis described laiko tragoudi as a complex cultural creation that was associated with the new living conditions of the proletariat in urban society and was influenced by the culture of refugees from Asia Minor and manghes songs. This fertile merging of the mystique of the manghes world with the nostalgic sentiments and the traumatic experience of the life of refugees contributed to the creation of a new "clear" popular song that expressed the most important problems of the working class. The taverns where the rebetika were performed became the places where the longing and torment of day-workers found expression in a world of ephemeral pleasures. It was a "heroic way to escape" the misery of the daily routine, since the long-sought-after maturation of the proletariat was not coming. ${ }^{99}$ Although these writers did not regard rebetika as songs with fighting spirit, they did see it as a deep, true, and authentic song that mirrored views of the proletarian world in urban areas.

Vournas also criticized the supporters of the "sacred ideological war" against rebetika, who perceived it as the product of a rotten world. He wondered why people with fighting spirit, who had the "miraculous intuition" to oppose decadent cultural forms and social oppression, were unable to resist the supposed cultural manipulation that came from the rebetika and "stuck to them, like a fly sticks on honey." This ironic questioning reflects the embarrassment of the Leftist intelligentsia in its effort to understand the great popularity among working class of a musical genre whose elements transgress the moral and political criteria of socialist realism. ${ }^{100}$

Vournas used familiar Marxist evolutionary schemes to explain the transition of rebetika from the cultural expression of some marginal groups with deviant social norms to the environs of taverns frequented by refugees from Asia Minor, where it was gradually subject to uplift. Despite his sympathy for the rebetika, Vournas, like many of his comrades, continued to reject the suspect facets of the genre, namely the "vulgar and decadent" element of some songs about prisons, brothels and hashish, and praise the

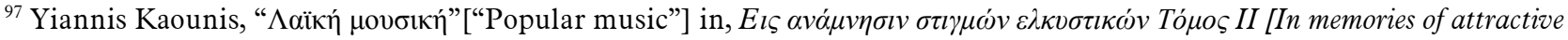
moments Vol. II) Panayiotis Kounadis, (Athens, 2003), 488-492. First publication in manuscript on Tetradia, an illegal magazine of Left-wing prisoners (1970): 5-6.

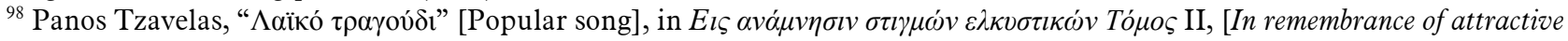
moments, vol. II], Kounadis, 503-509; first publication in Tetradia 5-6 (1970).

${ }^{99}$ Kostas Sofoulis, "Epistoli” [Letters].

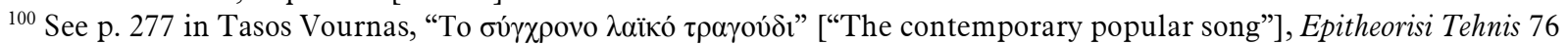
(1961): 277-285; reprinted in, Gail Holst-Warhaft (1991), 164-185 (see p.165).
} 
"pure" rebetika which became "the musical equivalent of working masses in urban places" singing the pain, torments, and passions of downtrodden people. ${ }^{101}$

A similar explanatory scheme was advanced by Theodorakis, ${ }^{102}$ who defined authentic popular song as a cultural creation that "mirrored the life and feeling of working people," capturing "the love, torment, and valor of the proletariat in urban centers." These tensions appeared in some post-war "rebetika" (which should be properly described as laika and not rebetika) and were characterized by the "dignity, chivalry and tenderness of the popular lover." These songs were considered to have no relationship to the hashishsongs of the past, which, since their words were about the disreputable aspects of life, were not acceptable to the masses. He claimed that the older rebetiko composers were sensitive and emotional artistic figures who responded to their disappointment with the squalid living conditions they encountered, and sought in hashish an escape and a relief. Despite its defiant content, the composer expressed his preference to rebetika given that the "burning truth" of their melodies broke their way through the "rotten wall of the teke" and spilled into the working-class neighbourhoods and factories. ${ }^{103}$ The argument came to an ambivalent conclusion: although the people were moved by rebetika melodies they did not accept the stalemate of the fatalistic lyrics, seeking instead a real popular song to express their deeper social needs.

Part of the rhetorical strategy used by the supporters of rebetiko was to focus on negotiations about its disreputable associations, which were a thorn in the side of the Marxist intellectuals, since their ideological commitments to the communist principles did not allow to them to accept these "immoral" aspects of the genre. In order to overcome this obstacle, they used a binary distinction between the "pure" popular rebetika song, which appeared to constitute an important part of the noble heritage of the subjugated classes, and the low-brow song referring to hashish, prisons and brothels that were seen as the "Lower Other" and not worthy of the term popular.

Other writers praised the ways in which rebetika expressed the daily passions of the people and their vivid melodic and poetic originality. They distinguished them from the hashish-related and low-life songs that mirrored the social life of wretched social strata living conditions and had a negative impact on the working people. ${ }^{104}$ Espousing a conspiracy theory, they saw the production of low-brow songs as a result of the State apparatus diffusing drugs among the masses in order to control proletarian resistance against bourgeois ideology. They argued that it was the task of the State apparatus to prevent people from the enterprising interests that circulate drugs, "poisoning" the spirit of people. ${ }^{105}$ At the same time, the progressive movement should criticize and change the socio-economic factors that had given rise to social degradation and backwardness and led to deviant behaviour and drug culture. ${ }^{106}$

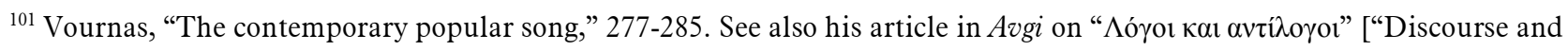
retort”], February 27, 1977.

${ }^{102}$ Theodorakis dedicated his life and artistic creativity to put into action his political aspiration of the formation of a higher form of popular song that could humanize the masses, raise lower classes, and stimulate national consciousness. Even today, he defends his decision to compose songs for the masses and emphasizes the significance of his past experiences amongst political prisoners. According to his view, it was this experience of the company with "the man in the streets" that helped him to cultivate his artistic temperament and human sensibility. See the interview of Mikis Theodorakis to Spyros Aravanis. Dhifono 154 (2008): 4.

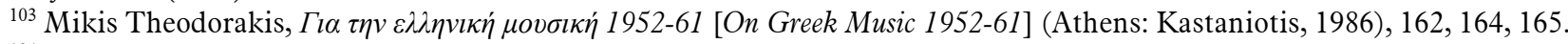

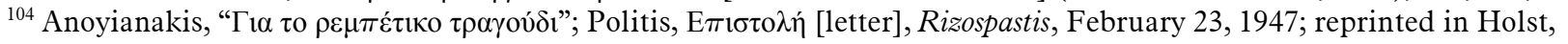
Road to rebeika, 144.

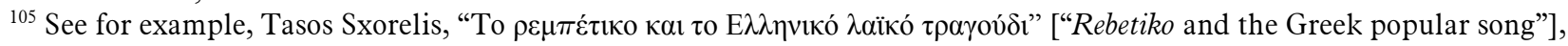
Rizospastis, March 24, 1976. See also Politis, "Letter."

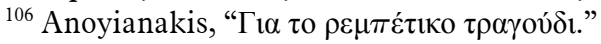




\section{The policy of rebetika cleansing}

For Marxists inspired by the vision of an imminent communist utopia, the solution to the rebetika issue was the creation of a new, civilizing popular song disconnecting the proletariat from low-brow songs and offering new ways of expression that encouraged chivalry, optimism, valour, and hope for a better world. In this vein, Vasilis Papadimitriou released his proposal for a Marxist cultural policy of cleansing rebetika in early 1949. In his words, "by cleansing these songs not only do we root out a hotbed of pollution, which infects, spiritually and mentally the people and especially, [...] the youth but also set some good elements that exist $[\ldots]$ in the rebetika free to progress, develop and enter in the framework of a real popular song." 107

Theodorakis also put forward the need for a Leftist policy in the field of popular music. He used a rhetorical strategy based on an amalgam of patriotic and Marxist arguments to propose the formation of a higher form of popular music. The latter would express in an authentic way the noble anthropological qualities of Greeks and their cultural traditions, producing an unmediated, transparent expression of the national psyche within global music. According to his view, the policy-makers in the field of music failed to respond "to their main, historical role" to create songs reflecting "the soul and the pulse of Greek people," offering hope, and promoting a militant consciousness. What was needed was the creation of a national music school by progressive composers, who would put the music in the service of the education of masses, gearing them to the goals of the socialist vision.

Popular music produced by this school should "assimilate creatively elements that derived from the noble traditions of the nation, such as dimotiko song, rebetiko and the Byzantine chants," [and then] reanimate and re-create them in a superior form of song. It was expected to offer new ways of melodic and social expression for people as well as the opportunity to communicate with the high virtues and ideals of Greek poetry. ${ }^{108}$

The arguments of Theodorakis were a sensation in musical circles, and the issue of cleansing the rebetika, along with the promotion of an elevated popular song, attracted the attention of other Left-wing intellectuals. Among rebetiko critics, Machairas disapproved of the "musical stench of rottenness and corruption" of rebetika and incited Left-wing composers to create a pure popular song compatible with the vision of a future classless society, a progressive song, "fighting, happy, optimistic, and full of hope towards a new peaceful and great era." 109

Vournas proposed that responsible musical composers should refine and cleanse rebetika of some undesirable traits (staleness, hedonism, fatalism, values of pleasure), otherwise it is "condemned" to remain in "the circles of social hell." ${ }^{110}$ Persisting with this religious metaphor, the way to the communist paradise was by taking hold of the polluted forces of capitalist "hell."

Yiannis Skouriotis, one of the ardent proponents of purging Greek popular music from the shame of rebetika, presented his arguments in a series of articles in the second half of 1950s. He considered rebetika a type of song associated with the "dens, and disreputable houses and streets," where various "wretched men lived a dark and subhuman life." In accordance with his binary conceptions, rebetika expresses the

\footnotetext{
${ }^{107}$ Papadimitriou, "Rebetiko song and its today supporters," 48.

${ }^{108}$ Theodorakis, [On Greek Music], 168-9.

${ }^{109}$ Machairas, "The rebetiko and the contemporary popular song," 84-99.

${ }^{110}$ Vournas, “The contemporary popular song," 284-5.
} 
"unhealthy" side of common people: the lumpen-proletariat and the underworld as opposed to the "healthy" side of the people- the socially conscious proletariat that possessed fighting spirit, "balanced mood," and "moral vigour." Following an evolutionary theoretical scheme, he claimed that in the pre-war era, the influence of rebetika on the masses was limited to the closed atmosphere of taverns, away from the private life of respectable working people. Eventually, its influence spread due to the co-existence and the interaction between the "salubrious" and the "unhealthy" elements of the proletariat. As a result, the respectable working class imitates accept lumpen conduct and types of expression of the "polluted" atmosphere of the "social gutter." 111

Elaborating on the influences commercial rebetika had upon upper classes in the post war period, he claimed that the discovery of the liberal atmosphere of rebetika taverns by "high society" strengthened the ties between some bohemian circles and the rebetes because of common hedonistic values that found expression in these songs of escape, passion, and vice, and spread moral corruption to the entire society. Supporting the need for the catharsis of the genre from its less "salubrious" side, he calls for the collective action of the progressive intelligentsia in order to isolate the "infectious influences" of rebetika in the restricted circles of the underworld. According to his teleological belief, the only drastic solution to the problem was the radical transformation of the social and economic system that would efface the "root of evil": the social conditions that bred the unhealthy and anti-social part of the people and their alienated cultural products. ${ }^{112}$

The way that Skouriotis approached the rebetika issue is a remarkable example of the vague understanding of the genre that often went hand in hand with politically motivated arguments. Skouriotis, like many other opinion-leaders, evaluated rebetiko within the context of a class-centred analysis which focused its interest on the potential role of music in the political indoctrination of working classes. Leftist rebetologists tried to identify a new "pure" popular song that could respond both to the "real" needs of the people and the hope for a better world. In doing so, they believed themselves to be performing a humanitarian role-in Tragaki's words, "a missionary for humanity unveiling deceit and hypocrisy, attacking false hierarchies and combating injustices and inequalities." commitments to particular courses of action are cultural constructions that have an identifiable structure consisting of symbolic boundaries. ${ }^{114}$ In rebetika discourse, the attempt to find a "pure," "salubrious," and optimistic popular song was closely connected to the commitment to a higher moral order of equality, freedom, and social justice that was expected to come into being with the advent of a communist paradise.

It is clear that Marxist intellectuals took no notice of people's feelings and perceptions of popular music since they believed that working people were trapped by the false ideology of hegemonic culture. As a result, they regarded themselves as the responsible group that could promote class-consciousness and promulgate Marxist morals, cultural tastes, and ideological precepts among the masses. The applicability of this dogmatic belief, proved limited, and led to a narrow-minded, moralistic, if not racist, evaluation of the

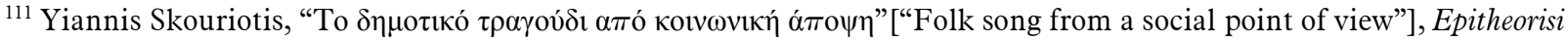
Tehnis 20 (1956): 151-2.

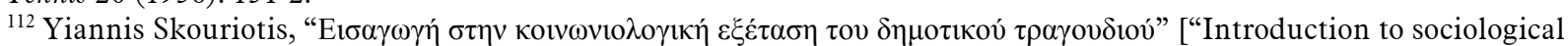
examination of folk song"], Koinoniologhiki Ereuvna 1 (1957a): 55-66 (especially p. 55-6); Yiannis Skouriotis,

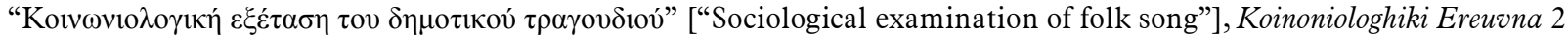
(1957b): 142-152. Both articles are reprinted in Vlisidis, Rare texts about rebetiko, 234-241.

113 Tragaki, "Humanizing the masses," 54.

${ }^{114}$ Wuthnow, Meaning and moral order, 95.
} 
rebetika, based on political standards that set aside both artistic criteria and the issue of the genre's popularity.

The urgency of anti-rebetika discourse concerning the removal of low-brow associations from popular music prepared the ground for musical innovations and cultural changes in the post-war era. Indeed, the hashish-related songs gradually disappeared and the rebetika subculture values were on the decline. In the world of popular music, two new musical styles were born by using selective elements of rebetika in the framework of the new gentler, less questionable and controversial, types of music accessible to a wider audience.

The first was a hybrid bouzouki-style song called "new laiko tragoudi"115 or "laika" music," "116 based on the rebetiko tradition incorporating elements derived from western and Latin rhythms, Turkish, Arabian, and Egyptian music. ${ }^{117}$ As Pennanen notes, these songs were performed in night-clubs (bouzoukia) and used "electrical amplified ensembles and a new type of bouzouki with four double strings instead of the traditional three." 118 In comparison with the rebetika, their lyrics become blander and gentler and were not associated with disreputable themes. In this way, the laika songs gained the respect of a much wider audience suited to the needs of recording market, but lost the peculiar, often radical, character of their ancestors.

Despite the fact that this musical style became extremely popular among the lower classes and, to some extent, particularly in the case of numerous songs sung by Stelios Kazantzidis, dealt thematically with some of the most important problems of subordinate classes of that era (poverty, fatalism, migration, injustice, inequity, and the underdog), the Marxist intelligentsia paid little attention. Ironically, it was the aura of mystique and the impure content of the rebetika that attracted their attention and provided an opportunity for discussion about broader political and moral issues.

The second style was the so-called entexno laiko tragoudi (art-popular song), which was initiated by classical-trained composers Hatzidakis and Theodorakis. They set noble Hellenic poems to music and used eminent popular singers (for instance, Grigoris Bithikotsis, Stelios Kazantzidis, Marinela, Mary Linda), as well as traditional musical instruments and melodies in the performances of the songs. This new musical style was promoted as a higher form of popular song, ${ }^{119}$ offering many Leftist songwriters the opportunity to practice their political aspiration to create national popular songs that could express both the rich musical heritage of the nation and the militant and subversive spirit of a pure proletarian song.

It should be noted that the post war transition from the "sinful" and "dangerous" rebetika to the stage of the virtuous popular song could be seen as a lens through which we could view wider social transformations and cultural changes. Indeed, the history of rebetika is interrelated with the processes of moralization, westernization, modernization, commercialization, ethnic entanglement, and migration that have occurred in modern Greece-and also in many other countries as I have discussed above.

\footnotetext{
${ }^{115}$ Michel, "Tsitsanis and the birth of the 'new' laiko song," 55.

${ }^{116}$ Pennanen, "The development of chordal harmony in Greek rebetika, 1930s to 1960s," 65.

117 ibid., 67.

118 idid., 65.

${ }^{119}$ Dimitris Papanikolaou, Singing poets: Literature and popular music in France and Greece (Oxford: Legenda, 2007).
} 


\section{Conclusion}

In numerous militant and vivid articles on rebetika, Marxist opinion-leaders dealt with the issues of Greekness and class associations of the genre. Many communist writers, infused with a spirit of patriotism, searched for an uncorrupted indigenous Greek culture. According to Marxist thought, a national culture should be identified with the noble and heroic traditions of people who resisted the various conquerors of the nation and the exploitation of the ruling classes. As a result, foreign or bourgeois musical influences were perceived as evidence of national decay or as a vehicle of an imperialist plan to alienate the militant consciousness of the people.

Those opposed to rebetika, perceived the eastern elements of the genre as an undesirable residue of the Ottoman occupation and looked askance at the promotion of rebetika by State Radio. Alongside western rock music, rebetika were seen as traces of wider imperialistic plans to corrupt Greek youth, inculcating in them the values of individualism, pleasure, and hedonism. Supporters of rebetiko claimed that it had origins in the glorious past of the nation, retaining the trace of Hellenistic civilization. Selectively utilizing historical documents, they identified rebetika either with the Byzantine Empire or the western secular tradition, offering ambiguous explanations that reflect Greek anxieties about their modern identity, and their ambiguous position between the Orient and Occident.

It is clear that the rich syncretic nature and hybridity of rebetiko, which some writers pointed out (Anoyianakis, for example), put obstacles in the way of Leftist rebetologist's attempts to interpret the genre through simple generalizations and dualistic schemes. The understanding of the various stages of the crossfertilization of rebetika, its intercultural and, even, supranational elements, demanded a kind of criticism that could move beyond prevalent notions of nation and romantic ideals.

For the Marxist intelligentsia, the term "popular," like the word "national," had an inherently positive meaning. Indeed, the popular song was seen as a higher kind of music that would express the deeper needs, desires, and pains of people, particularly the working people and the under-privileged classes. Following the principles of socialistic realism, popular song was expected to be inspired both by a "heroic" musical past, assimilating creatively resistant elements from the traditional and folk culture, and also from the hard social reality of subordinate classes in the modern world. In this way, nostalgia for an idealized musical past was coupled with the demand for a modern social song in the service of the people, facilitating the transition from the disreputable traits of pre-war song to some alleged higher form of popular songs in the post-war era.

The supporters of rebetika met with greater difficulties interpreting the genre so that its lowbrow associations were aligned with Marxist political aspirations. Nevertheless, some of them went against the prevalent notional schemes, seeing aesthetic value and radicalism in rebetika, and singling out its mysticism, Dionysiac elements, nonconformist spirit, passion, and primitivism. From this perspective, rebetiko was a type of counter-culture that challenged the bourgeois or petit-bourgeois system of values, at least at a cultural level. Thus, some sympathizers imbued with a romantic spirit attempted to combine the mystique of marginality and the hidden, oriental aspects of Hellenism with the political aim of promoting the struggle of working people against western imperialistic forces.

While for the champions of rebetika, its innovative music and association with the marginal world was attractive, for its opponents, the liberating and hedonist content of the genre challenged the moral standard and ideals of communist movement. Indeed, for the "orthodox" side, rebetiko was considered to be a fatalistic, pessimistic, defeatist, and apolitical genre that deflected the interest of the proletariat away 
from the class struggle, serving the aims of the dominant ideology. For these reasons, people should avoid the "polluted" forces of rebetiko and the concomitant patterns of behaviour and ways of thinking.

Since Marxist opinion-leaders were obsessed with a sense of responsibility to reinforce the militant consciousness of people, the intervention of the Marxist avant-garde in daily life and culture was perceived as one of its most important political tasks in the struggle against reactionary forces. In the field of popular music, Marxist intellectuals encouraged popular and classically-trained Marxist songwriters to create a socially conscious song praising the real virtues and traits of the people (passion, love, kindness, and deep feelings) and offering utopian images of an ideal communistic paradise. The cultural policy of cleansing rebetika was promoted mainly by some moderate supporters of the genre, who distinguished the "salubrious" from the "unhealthy" side of rebetika, proposing its release from the underworld associations and its gradual inclusion into a higher form of national-popular song.

The analysis of rebetika discourse within Greek Marxist circles reveals a political thought based on binary schemes (for example salubrious-unhealthy, optimistic-fatalistic, pure-impure, political-apolitical, bourgeois culture-proletarian culture, sinful-virtuous, capitalist hell-communist paradise). In this manner, an epic struggle was depicted between the moral order of an idealized "pure," and militant proletariat against the reactionary forces of capitalist society. These cultural constructions seem to have been formed in the ideological climate of the political conflicts during the Greek Civil War, which scarred the defeated Left wing, spreading fears and insecurities among their persecuted members. In this context, the Left organized its political actions against hegemonic culture and the oppressive socio-political control system that had been established by the Right-wing State. ${ }^{120}$ In the spirit of the cold war climate of this era, Leftists learned to "grin and bear" their persecution, confident that it would give way to a communist paradise. According to a deep-rooted "theological" belief, the way toward the utopian communist world goes through the political and cultural control of the infectious forces of the capitalist "evil" and its cultural products, including rebetika, either in its entirety or in its unhealthy aspects.

During the last quarter of twentieth century, long held convictions about an imminent Utopia were shaken by the rise of new social movements, the revolutionary climate of May '68 in France and, mainly, the collapse of the communist regime in Eastern Europe in the 1990s. As a result, the devotion to the strict rules of the communist leadership concerning the demonstration of the moralistic Marxist precepts about social life has wavered. In the last decades, discussions about rebetika remain vibrant, however, and Marxist intellectuals' attention seems to have moved away from the commitment to a sacred, political theology. Today, in rebetika haunts of Greek urban centres, people enjoy themselves listening and dancing to the "forbidden fruits" of sinful marginality, experiencing the strong appeal of the genre without any guilt. The mystique of the rebetika world seems to have triumphed over past ideological biases and prejudices, since, ironically, the path towards the communist paradise proved to be unrealizable.

${ }^{120}$ Zaimakis, "Bawdy songs and virtuous politics," 33. 


\begin{abstract}
In the longstanding debate on rebetika, many Left-wing intellectuals became involved, linking music with the broader issues of the political and cultural struggle for hegemony. According to their view, popular music was expected to express the deeper social needs, feelings, and hopes of a militant proletariat and, at the same time, the virtuous inner self of the nation. In this way, the nostalgic attitude toward the romanticized national traditions of the race met the demand for a nobler type of popular song with a social content that expressed the nobility of the proletariat. Their analysis of texts about rebetika reveals traces of a theological faith in the advent of a utopian communist society and the potential role of the Marxist avantgarde in protecting people from the infectious forces of the capitalist "evil." Rebetika, either as a whole or in its unhealthy aspects, was perceived as a controversial cultural product that was an obstacle to the class struggle that would lead to socialist transformation.
\end{abstract}

